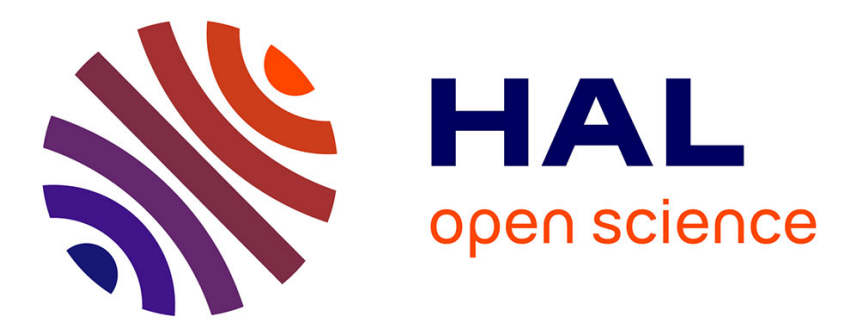

\title{
Application of a monoclonal-based immunoassay for the screening of imazalil in fruit juices
}

María-José Moreno, Emma Plana, Ángel Montoya, Pasquale Caputo, Juan

Manclus

\section{- To cite this version:}

María-José Moreno, Emma Plana, Ángel Montoya, Pasquale Caputo, Juan Manclus. Application of a monoclonal-based immunoassay for the screening of imazalil in fruit juices. Food Additives and Contaminants, 2007, 24 (07), pp.704-712. 10.1080/02652030701243101 . hal-00577551

\section{HAL Id: hal-00577551 \\ https://hal.science/hal-00577551}

Submitted on 17 Mar 2011

HAL is a multi-disciplinary open access archive for the deposit and dissemination of scientific research documents, whether they are published or not. The documents may come from teaching and research institutions in France or abroad, or from public or private research centers.
L'archive ouverte pluridisciplinaire HAL, est destinée au dépôt et à la diffusion de documents scientifiques de niveau recherche, publiés ou non, émanant des établissements d'enseignement et de recherche français ou étrangers, des laboratoires publics ou privés. 


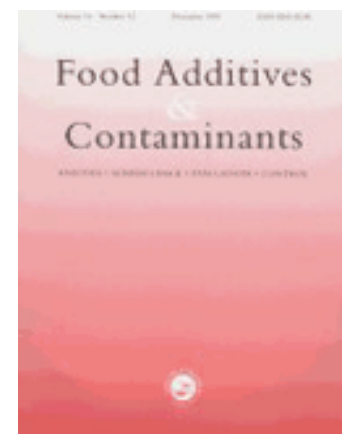

\section{Application of a monoclonal-based immunoassay for the screening of imazalil in fruit juices}

\begin{tabular}{|c|c|}
\hline Journal: & Food Additives and Contaminants \\
\hline Manuscript ID: & TFAC-2006-313.R1 \\
\hline Manuscript Type: & Original Research Paper \\
\hline $\begin{array}{r}\text { Date Submitted by the } \\
\text { Author: }\end{array}$ & 16-Jan-2007 \\
\hline Complete List of Authors: & $\begin{array}{l}\text { Moreno, María-José; Universidad Politécnica de Valencia, Instituto } \\
\text { de Investigación e Innovación en Bioingeniería } \\
\text { Plana, Emma; Universidad Politécnica de Valencia, Instituto de } \\
\text { Investigación e Innovación en Bioingeniería } \\
\text { Montoya, Ángel; Universidad Politécnica de Valencia, Instituto de } \\
\text { Investigación e Innovación en Bioingeniería } \\
\text { Caputo, Pasquale } \\
\text { Manclus, Juan; Universidad Politécnica de Valencia, Instituto de } \\
\text { Investigación e Innovación en Bioingeniería }\end{array}$ \\
\hline Methods/Techniques: & Immunoassays, Screening - ELISA \\
\hline Additives/Contaminants: & Pesticide residues \\
\hline Food Types: & Fruit juices \\
\hline
\end{tabular}

\section{SCHOLARONE Manuscripts}




\begin{abstract}
A monoclonal antibody-based enzyme-linked immunosorbent assay (ELISA) was developed for the quantification of imazalil [(RS)-1- $\beta$-allyloxy-2,4dichlorophenylethyl)imidazole] in apple, tomato and orange juice samples. From an imazalil hapten which mimics the analyte structure, several monoclonal antibodies were obtained. An ELISA in the conjugate-coated format was developed and optimized using the antibody showing the highest sensitivity. For standards, the detection limit of the ELISA was $0.2 \mathrm{nM}\left(0.06 \mathrm{ng} \mathrm{ml}^{-1}\right)$, with an $\mathrm{I}_{50}$ value of $1.6 \mathrm{nM}\left(0.5 \mathrm{ng} \mathrm{ml}^{-1}\right)$. The study of the influence of the matrices on the assay reliability indicated that the ELISA could determine imazalil in fruit juices at the low $\mathrm{ng} \mathrm{m}^{-1}$ level simply by diluting the sample, without any clean-up or concentration step. Recovery and precision of the method were evaluated by spiking juice samples with imazalil in the $10-500 \mathrm{ng} \mathrm{ml}^{-1}$ range. The mean recovery from fruit juices was $97 \%$ and the mean coefficient of variation was around $20 \%$. In addition to being precise and accurate, the method has proved to be simple and sensitive, with a quantification limit well below the maximum residue limits for imazalil in these matrices.
\end{abstract}

Keywords: Imazalil; Azole fungicide; Monoclonal antibodies; Immunoassay; ELISA; Fruit juices. 


\section{Introduction}

Imazalil [(RS)-1- $\beta$-allyloxy-2,4-dichlorophenylethyl)imidazole], is a systemic imidazole fungicide used to control a wide range of fungi on fruit, vegetables, and ornamental plants. It is also used for the treatment of barley and wheat seeds prior to planting, and to treat equipment and egg storage areas in chicken hatcheries. Imazalil was initially classified as likely to be carcinogenic in humans, but recent studies have provided sufficient evidence that imazalil is a threshold carcinogen. Exposure studies concluded that there is a reasonable certainty of no harm to any population subgroup from aggregate exposure to imazalil from dietary (food and water) exposure and all other non-occupational sources. On the basis of risk quotients, imazalil used at the recommended application rates should not result in an acute or chronic risk to mammal and avian species. Imazalil is moderately toxic to rats, freshwater fish and invertebrates following acute exposure. Results of imazalil ecological risk assessments show that none of the risk quotient values exceed the level of concerns for either terrestrial or aquatic non-target organisms. Fate studies showed that imazalil degrades slowly in soil and is not mobile, which mitigates the likelihood that this chemical will reach surface water and accumulate in fish (US Environmental Protection Agency 2006; Tomlin 1997). As mentioned above, imazalil is particularly widely used for post-harvest treatment of citrus, banana, and other fruit to control storage decay. Due to this application, imazalil residues can remain in fruit and, obviously, in their derivatives. This fact poses the need to establish legal directives to control their levels through the Maximum Residue Levels (MRLs), which are established by each country. In this sense, in Europe, the current legislation allows imazalil residue levels of up to $5 \mathrm{mg}$ $\mathrm{kg}^{-1}$ in fresh fruit (FAO/WHO 2006). Therefore, it is necessary to develop of appropriate analytical methods for the follow-up of imazalil residues in food. 
Imazalil has been analysed by various chromatographic methods. They involve different extraction procedures followed by gas chromatography (Garrido et al. 1997; Matsumoto 2001; Yamazaki and Ninomiya 1996), liquid chromatography (Blasco et al. 2006; Yoshioka et al. 2004; Zamora et al. 2004) or gas-liquid chromatography (López and Riba 1999) analysis, coupled to different detection systems. The limits of detection of these techniques were in the range of 1-100 $\mathrm{ng} \mathrm{g}^{-1}$. Recently, a new method for rapid quantification of imazalil in citrus fruit has been developed, which uses flow-injection electrospray ionization tandem mass spectrometry (Ito et al. 2003). To date, these chromatographic methods are the most used, but they generally require a laborious sample pre-treatment and high-cost equipment. Immunochemical techniques, mainly enzyme-linked immunosorbent assays (ELISA), are alternative or complementary analytical tools to conventional methods. Immunochemical methods are based on the interaction of an analyte with an antibody that recognizes it with high affinity and specificity. They are simple, cost-effective, and field-portable, do not require sophisticated instrumentation, and are able to analyse a large number of samples. In practice, one of the most important advantages of immunoassays for pesticide analysis lies on their minimal requirement of sample cleanup. Over the last decade, several ELISAs based on polyclonal antibodies for residue analyses of azole fungicides have been developed (Cairoli et al. 1996; Chen et al. 1996; Forlani et al. 1992). Nevertheless, the amount of antiserum produced by even a group of animals is limited, and its characteristics vary from animal to animal and also between different breedings from the same animal. Monoclonal antibodies (MAb) can be produced in unlimited quantities and offer the possibility to standardize the assay method. Recently, the development of a sensitive ELISA for the detection of imazalil in citrus fruits samples based on monoclonal antibodies has been described (Watanabe et al. 2000). This ELISA required 
imazalil extraction from samples, although no further clean-up was needed other than appropriate dilution of filtrated methanolic extracts. The same authors used this MAb in an immunoaffinity column clean-up for imazalil determination in citrus fruits by HPLC (Watanabe et al. 2001).

The analysis of fungicide residue in juice matrices by immunoassays offers considerable advantages over chromatographic techniques, since analyte extraction is not required and samples could be directly analysed by diluting them adequately. Therefore, the aim of this work was to obtain MAbs to imazalil for the development of enzyme-linked immunosorbent assays, whose analytical parameters could allow the simple detection of imazalil in fruit juice samples with a high sample throughput.

\section{Materials and methods}

Reagents and instrumentation

Analytical standard of imazalil and azole fungicides were from Riedel-de Haën (Seelze, Germany). Working stock solutions were prepared in N,N-dimethylformamide and stored at $-20^{\circ} \mathrm{C}$. Analytical grade solvents and silica gel $60,0.06-0.2 \mathrm{~mm}$, for column chromatography, were from Scharlau (Barcelona, Spain). Imazalil precursor, 1-(2, 4dichlorophenyl)-2-(1-imidazolyl) ethanol, was from Acros Organic (Geel, Belgium). Potassium hydride $30 \%$ wt dispersion in mineral oil, ethyl 6-bromohexanoate, ovalbumin (OVA), o-phenylenediamine (OPD), Sephadex G-50, and Freund's complete and incomplete adjuvants were obtained from Sigma-Aldrich Química (Madrid, Spain). Bovine serum albumin fraction V (BSA), enzyme-immunoassay grade horseradish peroxidase (HRP), hybridoma fusion and cloning supplement (HFCS), and polyethylene glycol (PEG) 1500 were purchased from Roche Diagnostics (Barcelona, Spain). Peroxidase-labelled rabbit anti-mouse immunoglobulins was obtained from Dako 
(Glostrup, Denmark). Culture media (high-glucose Dulbecco's Modified Eagle's medium with GLUTAMAX I and sodium pyruvate, DMEM), fetal calf serum (Myoclone Super Plus), and supplements were from Gibco (Paisley, UK). Culture plasticware was from Corning (New York, USA). P3-X63-Ag8.653 mouse plasmacytoma line was from American Tissue Type Culture Collection (Rockville, USA). Polystyrene culture plates (High Binding Plates, cat. no. 3590) were from Costar (Cambridge, USA).

ELISA plates were washed with a 96 PW microplate washer from SLT Labinstruments GmbH (Salzburg, Austria), and absorbances were read in dualwavelength mode (490-650 nm) with a Emax microplate reader from Molecular Devices (Sunnyvale, USA). Ultraviolet-visible reported spectra were recorded on a UV160A Shimadzu spectrophotometer (Kyoto, Japan).

Preparation of imazalil protein conjugates

The structure of the imazalil hapten IMH [1-(2, 4-dichlorophenyl)-2-(1-imidazolyl) hexanoic acid] used to prepare imazalil protein conjugates is depicted in Figure 1. IMH was prepared by introduction of an alkyl chain spacer, ending in a carboxylic acid, by O-alkylation of the hydroxyl group of an imazalil precursor (Ito et al. 1998). [Insert Figure 1 about here]

Preparation of immunizing conjugates. IMH hapten was covalently attached to BSA using the modified active ester method (Langone and van Vunakis 1982) and the mixedanhydride method (Rajskowsky et al. 1977). According to the first method, $15 \mu$ mol of the hapten was reacted with stoichiometric amounts of N-hydroxysuccinimide and dicyclohexylcarbodiimide in $0.1 \mathrm{ml}$ of DMF overnight at room temperature. After centrifuging, $0.083 \mathrm{ml}$ of the clear supernatant containing the active ester was dissolved in $0.317 \mathrm{ml}$ of DMF and slowly added to $0.6 \mathrm{ml}$ of a $25 \mathrm{mg} \mathrm{ml}^{-1}$ BSA solution in $0.2 \mathrm{M}$ 
borate buffer, $\mathrm{pH}$ 9. The initial hapten to protein molar ration in the mixture was 55:1. The mixture was allowed to react at room temperature for $4 \mathrm{~h}$ with stirring, and finally the conjugate was purified by gel filtration on Sephadex G-50 using $100 \mathrm{mM}$ sodium phosphate buffer, $\mathrm{pH} 7.4$, as eluant. The extent of coupling of the hapten to BSA was estimated by the determination of the number of protein free amino groups before and after conjugation, using 2,4,6-trinitrobenzenesulfonic acid (TNBS) as the titration reagent (Habeeb 1966). The hapten to protein molar ratio was evaluated as 20. According to the mixed-anhydride method, $16.70 \mu \mathrm{mol}$ of the hapten was treated with stoichiometric amounts of tri-butylamine and isobutyl chloroformate in $0.229 \mathrm{ml}$ of DMF for $30 \mathrm{~min}$ at room temperature. To the reaction mixture was added DMF up to $0.4 \mathrm{ml}$, and was slowly added to a solution of $15 \mathrm{mg}$ of BSA in $0.6 \mathrm{ml}$ of $0.2 \mathrm{M}$ borate buffer, $\mathrm{pH}$ 9. The initial hapten to protein molar ration in the mixture was 73:1. After stirring for $2 \mathrm{~h}$ at room temperature, the conjugate was purified as above. The hapten to protein molar ratio in the conjugate was evaluated as 10 .

Preparation of the coating conjugate. IMH hapten was covalently attached to OVA using the mixed-anhydride method. The hapten $(11.2: \mathrm{mol})$ was treated with stoichiometric amounts of tri-n-butylamine and isobutyl chloroformate in $0.153 \mathrm{ml}$ of DMF for $30 \mathrm{~min}$ at room temperature. To the reaction mixture was added DMF up to $0.5 \mathrm{ml}$, and then was slowly added to $1.5 \mathrm{ml}$ of a $20 \mathrm{mg} \mathrm{ml}^{-1}$ OVA solution in $0.2 \mathrm{M}$ borate buffer, $\mathrm{pH}$ 9. The initial hapten to protein molar ration in the mixture was 17:1. After stirring for $2 \mathrm{~h}$ at room temperature, the conjugate was purified by gel filtration on Sephadex G-50 using $100 \mathrm{mM}$ sodium phosphate buffer, pH 7.4 as eluant. The extent of coupling of the hapten to OVA was determined by the TNBS protocol above described. The hapten to protein molar ratio in the conjugate was evaluated as 5 . 
Preparation of the enzyme tracer. IMH hapten was covalently attached to HRP using the mixed-anhydride method. 11.2 :mol of the hapten was treated with stoichiometric amounts of tri-n-butylamine and isobutyl chloroformate in $0.153 \mathrm{ml}$ of DMF for $30 \mathrm{~min}$ at room temperature. To $0.1 \mathrm{ml}$ of the reaction mixture was added $0.9 \mathrm{ml}$ of DMF, and $0.1 \mathrm{ml}$ of this dilution $(0.73: \mathrm{mol})$ was slowly added to $1 \mathrm{ml}$ of a $2.2 \mathrm{mg} \mathrm{ml}^{-1} \mathrm{HRP}$ solution in $0.2 \mathrm{M}$ borate buffer, $\mathrm{pH}$ 9. The initial hapten to protein molar ration in the mixture was 15:1. After stirring for $2 \mathrm{~h}$ at room temperature, the conjugate was purified by gel filtration on Sephadex G-50 using $100 \mathrm{mM}$ sodium phosphate buffer, $\mathrm{pH}$ 7.4, as eluant.

\section{Production of monoclonal antibodies to imazalil}

Four BALB/c female mice (8-10 weeks old) were immunized with the BSA-IMH conjugates. First dose consisted of $100: \mathrm{g}$ of conjugate intraperitoneally injected as an emulsion of $250: 1$ of a 1:1 (v/v) mixture of PBS (10 mM sodium phosphate, $137 \mathrm{mM}$ $\mathrm{NaCl}, 2.7 \mathrm{mM} \mathrm{KCl}, \mathrm{pH}$ 7.4) and complete Freund's adjuvant. Three subsequent injections were given at three-week intervals using the immunogen emulsified in incomplete Freund's adjuvant. After a resting period of at least three weeks from the last injection in adjuvant, mice received a final soluble intraperitoneal injection of conjugate in PBS, four days prior to cell fusion. Cell fusion and hybridoma selection procedures were carried out essentially as previously described by Manclús et al. (2004). Antibodies were directly purified from late stationary phase hybridoma culture supernatants by saline precipitation with saturated ammonium sulfate $(1: 1, \mathrm{v} / \mathrm{v})$, followed by affinity chromatography on a HiTrap Protein G column (Amersham Biosciences, Uppsala, Sweden). ELISA procedures 
ELISA plates were coated overnight with conjugate or antibody solutions in $50 \mathrm{mM}$ carbonate buffer, pH 9.6. A volume of 100 :1 per well was used throughout all assay steps, and all incubations were carried out at room temperature. After each incubation, plates were washed four times with washing solution $(0.15 \mathrm{M} \mathrm{NaCl}$ containing $0.05 \%$ Tween 20). Two basic formats were used depending on the assay component immobilized into the ELISA plates. In the conjugate-coated format, an indirect ELISA was used for the screening of culture supernatants, and a competitive indirect ELISA was used for the study of antibody sensitivity and specificity to analytes. In the antibody-coated format, the specific antibody was coated directly or by using a capture auxiliary antibody, and competitive ELISAs were followed to evaluate the assay properties using the HRP enzyme tracer. For competition assays the concentrations of antibodies, hapten conjugates, or enzyme tracers were optimized by checkerboard titration.

Conjugate-coated format. A competitive ELISA, based on an homologous conjugatecoated format, was chosen. Immunoassays were performed as follows: ELISA plates were coated overnight with $0.75: \mathrm{g} \mathrm{ml}^{-1}$ of OVA-IMH conjugate. Then, culture supernatant, or antibody dilutions in PBST (PBS containing 0.05\% Tween 20) were added and incubated for $1 \mathrm{~h}$. Next, plates were incubated for $1 \mathrm{~h}$ with peroxidaselabelled rabbit anti-mouse immunoglobulins diluted 1/2000 in PBST. Finally, peroxidase activity bound to the wells was determined by adding the substrate solution ( $2 \mathrm{mg} \mathrm{ml}^{-1}$ OPD and $0.012 \% \mathrm{H}_{2} \mathrm{O}_{2}$ in $25 \mathrm{mM}$ citrate and $62 \mathrm{mM}$ sodium phosphate, $\mathrm{pH}$ 5.35). After $10 \mathrm{~min}$, the reaction was stopped with $2.5 \mathrm{M}$ sulfuric acid, and the absorbance at $490 \mathrm{~nm}$ was read and recorded. For competitive assays, the procedure was the same except that after coating a competition step was introduced by adding $50: 1$ of 
the competitor followed by $50: 1$ of the appropriate concentration of antibody (culture supernatant or purified MAb).

Antibody-coated format. In this format, plates were coated overnight with monoclonal antibodies either directly at $1: \mathrm{g} \mathrm{ml}^{-1}$ or indirectly with goat anti-mouse immunoglobulins at $2: \mathrm{g} \mathrm{ml}^{-1}$. Next, the competition was established for $1 \mathrm{~h}$ between imazalil standards and the selected dilutions of the enzyme tracer. Peroxidase activity was measured as above.

\section{Preparation of imazalil standards and spiked juice samples}

From a $1 \mathrm{mM}$ stock solution of imazalil in DMF, serial dilutions in this solvent from 1 $\mathrm{mM}$ to $12.8 \mathrm{nM}$ were prepared. From these concentrations, standards from 2 :M to 25.6 pM were prepared by $1 / 500$ dilution in PBS. As the assay procedure involved the addition of the same volume of the appropriate immunoreagent concentration, imazalil standards in the final assay ranged from $1: \mathrm{M}$ to $12.8 \mathrm{pM}\left(297.17\right.$ to $\left.3.810^{-3} \mathrm{ng} \mathrm{ml}^{-1}\right)$. Tomato, orange and apple juices were obtained from a local supermarket and were used without any sample pretreatment. For ELISA determination, spiked juice samples were daily prepared by dilution in PBS, and each dilution was analyzed in triplicate. The imazalil concentration in the samples was calculated by averaging values obtained at each dilution.

\section{Data analysis}

Competitive curves were obtained by plotting absorbance values against the logarithm of analyte concentration. Using a commercial software (Sigmaplot, Jandel Scientific), sigmoid curves were fitted to a four-parameter logistic equation:

$$
y=\{(\mathrm{A}-\mathrm{D}) /[1+(x / \mathrm{C}) \mathrm{B}]\}+\mathrm{D}
$$


where $\mathrm{A}$ is the asymptotic maximum (maximum absorbance in absence of analyte, $\left.A_{\max }\right), B$ is the curve slope at the inflection point, $C$ is the $\mathrm{x}$ value at the inflection point (corresponding to the analyte concentration giving $50 \%$ inhibition of $\mathrm{A}_{\max }, \mathrm{I}_{50}$ ), and $\mathrm{D}$ is the asymptotic minimum. Imazalil concentration of fruit juice samples was determined by interpolation of the mean absorbance values on the standard curve run in the same plate (SOFTmax Pro Software, Molecular Devices).

\section{Results and discussion \\ Imazalil immunoassay development}

Imazalil, like most pesticides, is a small organic molecule which is non-immunogenic by itself and lacks a functional group for coupling to proteins. Therefore, the synthesis of pesticide-like molecules containing a functional group suitable for protein conjugation is a necessary and critical step in the production of high-affinity antibodies. The hapten IMH used to obtain monoclonal antibodies was synthesized by introduction of a spacer arm through the hydroxyl group of 1-(2, 4-dichlorophenyl)-2-(1-imidazolyl) ethanol, an imazalil synthesis precursor. Four cell fusion experiments were performed with each of the BSA conjugates of this hapten. In the screening of culture supernatants only wells showing a $50 \%$ signal inhibition in the presence of $1 \mu \mathrm{M}$ imazalil, with respect to that obtained in the absence of analyte, were considered as containing highaffinity antibody-secreting clones. From all fusion experiments, seven hybridomas fulfilled the above-mentioned criterion. These hybridomas were subsequently cloned and expanded in culture medium.

For the evaluation of the conjugate-coated format, non competitive experiments were carried out to estimate MAb titer. Thereafter, inhibition curves using imazalil as competitor were performed with the coating conjugate. Under these conditions, $\mathrm{I}_{50}$ 
values in the nanomolar range were obtained (Table I). With respect to the antibodycoated formats, noncompetitive experiments were carried out prior to inhibition assays. Concentrations of HRP-IMH conjugate from 2 to $0.016 \mu \mathrm{g} \mathrm{ml}^{-1}$ were tested in plates previously coated with the MAbs directly immobilized to the plate. HRP-IMH was only recognized by two MAbs (IMH-41 and IMH-42). Imazalil inhibition curves were performed for these two MAbs. $\mathrm{I}_{50}$ values of 118 and $130 \mathrm{nM}$ were obtained for IMH41 and IMH-42, respectively (Table I). The effect of a pre-coating step with goat antimouse Igs (indirect antibody-coated format) was also evaluated. This approach improved the assay sensitivity, as evidenced by a two-fold decrease of $\mathrm{I}_{50}$ values. As shown in Table I, among the monoclonal antibodies and ELISA formats evaluated MAb IMH-51 used in the conjugate-coated format provided the highest affinity ELISA to imazalil and, therefore, this combination of antibody and ELISA format was selected to carry out this study. The influence of the nonionic surfactant Tween 20, BSA (commonly used in ELISA to reduce nonspecific interactions), ionic strength, and $\mathrm{pH}$ on ELISA characteristics was examined (data not shown). The addition of Tween 20 to the assay buffer of the competitive step slightly improved the assay sensitivity (five-fold decrease of the $\mathrm{I}_{50}$ values). The highest assay sensitivity was achieved with a PBS buffer at neutral pH containing only a small amount of Tween $20(0.0025 \%)$.

[Insert Table I about here]

\section{Specificity of the imazalil immunoassay}

The specificity of the IMH-51 monoclonal antibody was evaluated by performing competitive assays with other imidazole and triazole pesticides and determining their respective $\mathrm{I}_{50}$ values. As shown in Table II, the assay was very specific for imazalil, since the assayed pesticides were not significantly recognized. In detail, the imidazole moiety has an important role in the analyte-antibody interaction since just the change to 
a triazole ring, while maintaining a similar exposed structure as represented by penconazole, drastically reduces the compound recognition (cross-reactivity $<0.12 \%$ ). Furthermore, the imazalil metabolite, from which the IMH hapten was synthesized, was poorly recognized.

[Insert Table II about here]

[Insert Figure 2 about here]

\section{Analytical characteristics of the imazalil immunoassay}

Figure 2 shows the standard curve obtained for the optimized imazalil competitive immunoassay with MAb IMH-51. This sigmoid curve was obtained by averaging 8 individual standard curves performed during the imazalil determination in juice samples. Prior to averaging, each individual curve was normalized by expressing the absorbance $\left(\mathrm{A}_{490}\right)$ as the percentage of the maximum response $\left(100 \mathrm{xA}_{490} / \mathrm{A}_{490, \text { max }}\right)$. Table III summarizes the variability of the mathematical parameters that define the sigmoid equation. Results are the average of 8 independent runs, each one fitted without normalization as used for direct interpolation of samples. Coefficients of variation (CV) were around $20 \%$ for $\mathrm{A}, \mathrm{B}$ and $\mathrm{C}$. The high $\mathrm{CV}$ of parameter $\mathrm{D}$ is due to the very low values obtained for asymptotic minimum absorbances, normally below the microplate reader precision. Referring to assay analytical parameters, the mean imazalil $\mathrm{I}_{50}$ value was $1.6 \mathrm{nM}\left(0.5 \mathrm{ng} \mathrm{ml}^{-1}\right)$ and the detection limit, estimated as the imazalil concentration that reduced absorbance to $90 \%$ of the maximum, was $0.2 \mathrm{nM}\left(0.06 \mathrm{ng} \mathrm{ml}^{-1}\right)$. The working range was defined as the concentrations giving $20-80 \%$ inhibition, i.e., $0.4-8.0$ $\mathrm{nM}\left(0.12-2.4 \mathrm{ng} \mathrm{ml}^{-1}\right)$. These parameters indicate that this ELISA can be considered sensitive enough for imazalil determination in fruit juices.

[Insert Table III about here]

Evaluation of matrix effects 
Food samples contain substances that may interfere in analyte determinations. These interferences are known as matrix effect. In immunoassays, these effects are manifested in different ways, the most common ones being a loss of assay sensitivity (increase of $I_{50}$ ) or a decrease of colour development (overestimate), though a combination of both effects is also possible. Thus, the influence of the selected juices on imazalil immunoassays should be determined prior to the application of the method to samples spiked with the analyte. With this idea in mind, two experiments were performed.

In a first experiment, the matrix influence on standard curve parameters was analysed. Imazalil standards were prepared in duplicate in PBS buffer containing a variable proportion of each juice. A decrease of the maximum absorbance and of the assay sensitivity were observed at matrix proportions higher than $1 / 25,1 / 50$ and 1/100 for tomato, orange, and apple juice, respectively (data not shown). These results suggested that imazalil could be analysed in juices simply by appropriately diluting samples in PBS, without the need of a cleanup step.

In a second experiment, juice samples were spiked with imazalil at several levels and they were properly diluted to give a concentration close to the midpoint of the working range. The objective of this experience was to determine the matrix dilution that provided accurate and precise determinations of imazalil. Table IV shows the statistical analysis obtained for each fortified juice sample determined four times at the indicated dilutions. Matrix effects were reduced to acceptable levels when tomato, orange and apple juice samples were diluted at least 1/25, 1/50 and 1/100, respectively, as proved by the recovery and the precision data obtained. Mean recoveries were 81.4 $\%, 100.8 \%$, and $97.7 \%$ for tomato, orange and apple, respectively, and most interassay CV were below $20 \%$.

[Insert Table IV about here] 


\section{Analysis of spiked juice samples}

To evaluate the performance of the imazalil immunoassay, fruit juices were spiked with known concentrations of imazalil in the $10-500 \mathrm{ng} \mathrm{ml}^{-1}$ range, and directly analysed by ELISA without any pre-treatment other than a 1/25, 1/50 and 1/100 dilution for tomato, orange and apple juice, respectively. After dilution, these fortification levels entered directly into the assay working range of the imazalil ELISA, and they are well below the maximum residue limits for imazalil in these crops $\left(2-5 \mathrm{mg} \mathrm{kg}^{-1}\right)$. Spiked samples were analysed four times independently. In order to obtain the imazalil concentrations, absorbances from triplicate wells were interpolated in the standard curve performed in the same plate. Table V summarizes the results obtained for each spiked juice sample. Coefficients of variation can be considered as acceptable, ranging from 8.3 to 30.8 , while recoveries were fairly good (mean values of $88 \%, 106 \%$, and $97 \%$ for tomato, orange and apple juices, respectively). Taking all together, linear regression analysis indicated a good correlation between the concentration of imazalil added to juice samples and the concentration determined by ELISA $\left(y=0.987 x-2.042, r^{2}=0.993\right)$. These results prove that this immunoassay is able to quantitatively detect concentrations of imazalil as low as $10-50 \mathrm{ng} \mathrm{ml}^{-1}$ in these juices.

[Insert Table V about here]

\section{Conclusions}

Following general guidelines for hapten design, IMH hapten was synthesized and used to produce monoclonal antibodies to imazalil. One of them, IMH-51, was selected for the development of a homologous indirect ELISA on the basis of its affinity and specificity to imazalil. The sensitivity of this immunoassay, expressed as the $\mathrm{I}_{50}$ value for standards, was $1.6 \mathrm{nM}$ imazalil $\left(0.5 \mathrm{ng} \mathrm{ml}^{-1}\right)$. Most important, the ELISA presented here is able to determine down to $10-50 \mathrm{ng} \mathrm{ml}^{-1}$ of imazalil in tomato, orange, and 


\section{Acknowledgements}

\section{References}

Blasco C, Font G, Picó Y. 2006. Evaluation of 10 pesticide residues in oranges and tangerines from Valencia (Spain). Food Control 17: 841-846.

Cairoli S, Arnoldi A, Pagani S. 1996. Enzyme-linked immunosorbent assay for the quantitation of the fungicide tetraconazole in fruits and fruit juices. Journal of Agricultural and Food Chemistry 44: 3849-3854.

Chen T, Dwyre-Gygac C, Hadfield ST, Willetts C, Breuil C. 1996. Development of an enzyme-linked immunosorbent assay for a broad spectrum triazole fungicide: hexaconazole. Journal of Agricultural and Food Chemistry 44: 1352-1356.

FAO/WHO Food Standards [internet] Rome (Italy): Pesticide MRLs, Pesticide Residues in Food. 2006 - [cited 2006 March 2]. Available from: http://www.codexalimentarius.net

Garrido J, de Alba M, Jiménez I, Casado E, Folgueiras ML. 1997. Chromatographic analysis of imazalil and carbendazim in fruits: Method validation and residue monitoring program 1995. Journal of Chromatography A 765: 91-97.

Forlani F, Arnoldi A, Pagani S. 1992. Development of an enzyme-linked immunosorbent assay for triazole fungicides. Journal of Agricultural and Food Chemistry 40: 328-331. 
Habeeb AF. 1966. Determination of free amino groups in proteins by trinitrobenzenesulfonic acid. Analytical Biochemistry 14, 328-336.

Ito S, Hayashi M, Watanabe S, Fujii A, Omoda N. 1998. Hapten compound and antibody of imazalil and measurement. Patent: JP10257886.

Ito Y, Goto T, Oka H, Matsumoto H, Miyazaki Y, Takahashi N, Nakazawa H. 2003. Simple and rapid determination of thiabendazole, imazalil, and o-phenyl phenol in citrus fruit using flow-injection electrospray ionization tandem mass spectrometry. Journal of Agricultural and Food Chemistry 51: 861-866.

Langone JJ, van Vunakis H. 1982. Radioimmunoassay of nicotine, cotinine, and $\gamma$-(3piridyl)- $\gamma$-oxo-N-methylbutyramide. Methods in Enzymology 84, 628-640.

López ML, Riba M. 1999. Residue levels of ethoxyquin, imazalil, and iprodione in pears under cold-storage conditions. Journal of Agricultural and Food Chemistry 47: $3228-3236$.

Manclús JJ, Abad A, Lebedev FM, Mojarrad F, Micková B, Mercader JV, Primo J, Miranda MA, Montoya A. 2004. Development of a monoclonal immunoassay selective for chlorinated cyclodiene insecticides. Journal of Agricultural and Food Chemistry 52: 2776-2784.

Matsumoto H. 2001. Simultaneous determination of imazalil and its major metabolite in citrus fruit by solid-phase extraction and capillary gas chromatography with electron capture detection. Journal of AOAC International 84: 546-550.

Rajskowsky KM, Cittanova N, Desfosses B, Jayle MF. 1977. The conjugation of testosterona with horseradish peroxidase and a sensitive enzyme assay for the conjugate. Steroids 29, 701-713.

Tomlin C. 1997. The pesticide manual: A world Compendium. The British Crop Protection Council: Farnham, Surrey, UK. p 691. 
US Environmental Protection Agency [internet]. Available from: http://www.epa.gov/oppsrrd1/reregistration/imazalil/. Accessed 2006 September 25.

Watanabe E, Watanabe S, Ito S, Hayashi M, Watanabe T, Yuasa Y, Nakazawa H. 2000.

Development of an enzyme-linked immunosorbent assay for the fungicide imazalil in citrus fruits. Journal of Agricultural and Food Chemistry 48: 5124-5130.

Watanabe E, Yoshimura Y, Yuasa Y, Nakazawa H. 2001. Immunoaffinity column clean-up for the determination of imazalil in citrus fruits. Analytica Chimica Acta 433: 199-206.

Yamazaki Y, Ninomiya T. 1996. Determination of imazalil residues in lemons by gas chromatography with nitrogen-phosphorus detection. Journal of AOAC International 79: 787-790.

Yoshioka N, Akiyama Y, Teranishi K. 2004. Rapid simultaneous determination of ophenylphenol, diphenyl, thiabendazole, imazalil and its major metabolite in citrus fruits by liquid chromatography-mass spectrometry using atmospheric pressure photoionization. Journal of Chromatograpphy A 1022: 145-150.

Zamora T, Pozo OJ, López FJ, Hernández F. 2004. Determination of tridemorph and other fungicide residues in fruit samples by liquid chromatography-electrospray tandem mass spectrometry. Journal of Chromatography A 1045: 137-143. 
Table I. Sensitivity of antibodies estimated as $\mathrm{I}_{50}$ values for imazalil $\left(\mathrm{ng} \mathrm{ml}^{-1}\right)$, obtained with different ELISA formats. ${ }^{1}$

\begin{tabular}{|c|c|c|c|}
\hline MAb & $\begin{array}{l}\text { Conjugate- } \\
\text { coated format }\end{array}$ & $\begin{array}{l}\text { Direct } \\
\text { antibody- } \\
\text { coated format }\end{array}$ & $\begin{array}{l}\text { Indirect } \\
\text { antibody-coated } \\
\text { format }\end{array}$ \\
\hline IMH-41 & 61 & 35 & 20 \\
\hline IMH-42 & 180 & 39 & 20 \\
\hline IMH-51 & 2 & $-{ }^{2}$ & - \\
\hline IMH-52 & 80 & - & - \\
\hline IMH-53 & 77 & - & - \\
\hline IMH-54 & 10 & - & - \\
\hline IMH-55 & 6 & - & - \\
\hline
\end{tabular}


Table II. Cross-reactivity ${ }^{1}$ of several compounds with LIB-IMH51 monoclonal antibody.

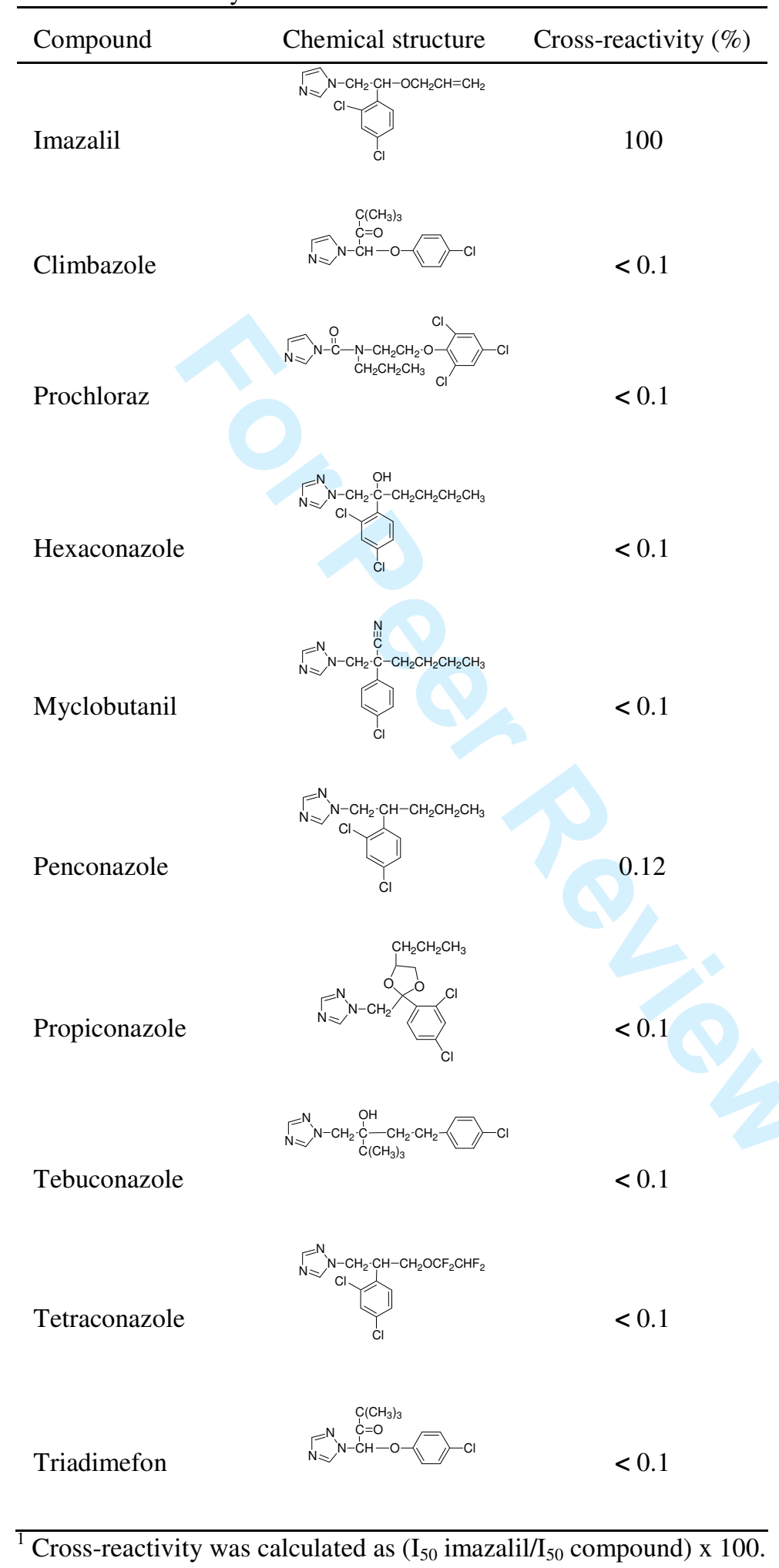


Table III. Variability of the mathematical parameters of the sigmoid standard curve. ${ }^{1}$

\begin{tabular}{lcccc} 
& $\mathrm{A}$ & $\mathrm{B}$ & $\mathrm{C}\left(\mathrm{I}_{50}\right)$ & $\mathrm{D}$ \\
\hline Mean $^{2}$ & 0.91 & 1.02 & 1.61 & 0.024 \\
$\mathrm{SD}$ & 0.2 & 0.21 & 0.4 & 0.012 \\
$\mathrm{CV}(\%)$ & 22 & 21 & 25 & 70 \\
Minimum & 0.64 & 0.8 & 1.03 & 0.008 \\
Maximum & 1.28 & 1.41 & 2.11 & 0.039
\end{tabular}

Asymptotic maximum absorbance (A), slope at the inflexion point (B), concentration value in $\mathrm{nM}$ at the inflexion point $(\mathrm{C})$, and asymptotic minimum absorbance $(\mathrm{D})$ are the parameters which fit the sigmoid equation $y=\left\{(\mathrm{A}-\mathrm{D}) /\left[1+(x / \mathrm{C})^{\mathrm{B}}\right]\right\}+\mathrm{D}$.

$$
{ }^{2} \mathrm{n}=8 \text {. }
$$


Table IV. Influence of matrix dilution on the reliability of the imazalil ELISA.

\begin{tabular}{lrrrcc}
\hline & $\begin{array}{l}\text { Spiked levels } \\
\left(\mathrm{ng} \mathrm{ml}^{-1}\right)\end{array}$ & $\begin{array}{l}\text { Sample dilution } \\
\text { factor }^{1}\end{array}$ & $\begin{array}{l}\text { Imazalil found }^{2} \\
\left(\mathrm{ng} \mathrm{ml}^{-1}\right)\end{array}$ & Recovery $(\%)$ & CV $(\%)$ \\
\hline Tomato & 10 & 5 & 5.1 & 51.0 & 33.4 \\
juice & 50 & 25 & 41.0 & 82.0 & 22.6 \\
& 100 & 50 & 75.9 & 75.9 & 20.4 \\
& 200 & 100 & 177.3 & 88.7 & 11.3 \\
Orange & 500 & 250 & 394.7 & 78.9 & 10.5 \\
juice & 10 & 5 & 26.2 & 262.0 & 21.7 \\
& 50 & 25 & 39.7 & 79.4 & 20.0 \\
& 100 & 50 & 102.8 & 102.8 & 14.5 \\
Apple juice & 200 & 100 & 213.0 & 106.5 & 24.2 \\
& 500 & 250 & 465.7 & 93.1 & 11.2 \\
& 10 & 5 & 3.3 & 33.0 & 73.6 \\
& 50 & 25 & 35.8 & 71.6 & 14.3 \\
& 100 & 50 & 76.5 & 76.5 & 29.6 \\
& 200 & 100 & 183.7 & 91.9 & 9.8 \\
& 500 & 250 & 516.9 & 103.4 & 19.8 \\
\hline
\end{tabular}

${ }^{\mathrm{T}}$ Sample dilution before adding to ELISA plate.

${ }^{2}$ Data obtained from five independent determinations. 
Table V. ELISA reproducibility and accuracy in spiked juice samples.

\begin{tabular}{|c|c|c|c|c|c|c|c|c|c|c|c|c|}
\hline & \multicolumn{12}{|c|}{ Imazalil spiked level $\left(\mathrm{ng} \mathrm{ml}^{-1}\right)$} \\
\hline & \multicolumn{4}{|c|}{ Tomato juice } & \multicolumn{4}{|c|}{ Orange juice } & \multicolumn{4}{|c|}{ Apple juice } \\
\hline & 10 & 25 & 50 & 100 & 25 & 50 & 100 & 250 & 50 & 100 & 250 & 500 \\
\hline $\begin{array}{l}\text { Mean value } \\
\text { found }{ }^{1}\end{array}$ & 9.7 & 22.8 & 35.0 & 94.6 & 33.4 & 44.1 & 98.8 & 262.2 & 36.2 & 108.0 & 273.6 & 486.7 \\
\hline SD & 1.6 & 5.4 & 8.5 & 19.4 & 10.3 & 11.1 & 22.3 & 39.2 & 3.5 & 28.2 & 44.1 & 40.2 \\
\hline $\mathrm{CV}(\%)$ & 16.5 & 23.6 & 24.3 & 20.5 & 30.8 & 25.2 & 22.6 & 14.9 & 9.7 & 26.1 & 16.1 & 8.3 \\
\hline Minimum & 8.7 & 17.7 & 26.8 & 72.2 & 21.8 & 33.6 & 73.9 & 217.1 & 32.7 & 75.7 & 224.4 & 440.3 \\
\hline Maximum & 11.6 & 27.8 & 44.2 & 107.3 & 43.5 & 54.3 & 116.8 & 287.8 & 39.7 & 127.8 & 309.6 & 510.3 \\
\hline Recovery (\%) & 97.0 & 91.2 & 70.0 & 94.6 & 133.6 & 88.2 & 98.8 & 104.9 & 72.4 & 108.0 & 109.4 & 97.3 \\
\hline
\end{tabular}

${ }^{\mathrm{T}}$ Data are the average of 4 independent determinations. 

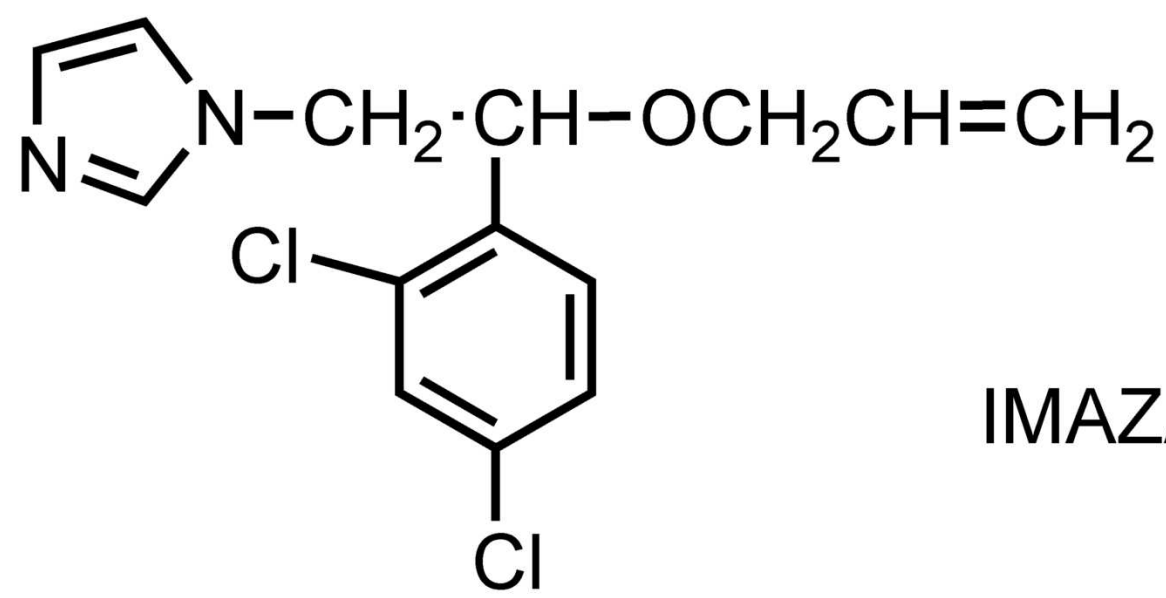

IMAZALIL

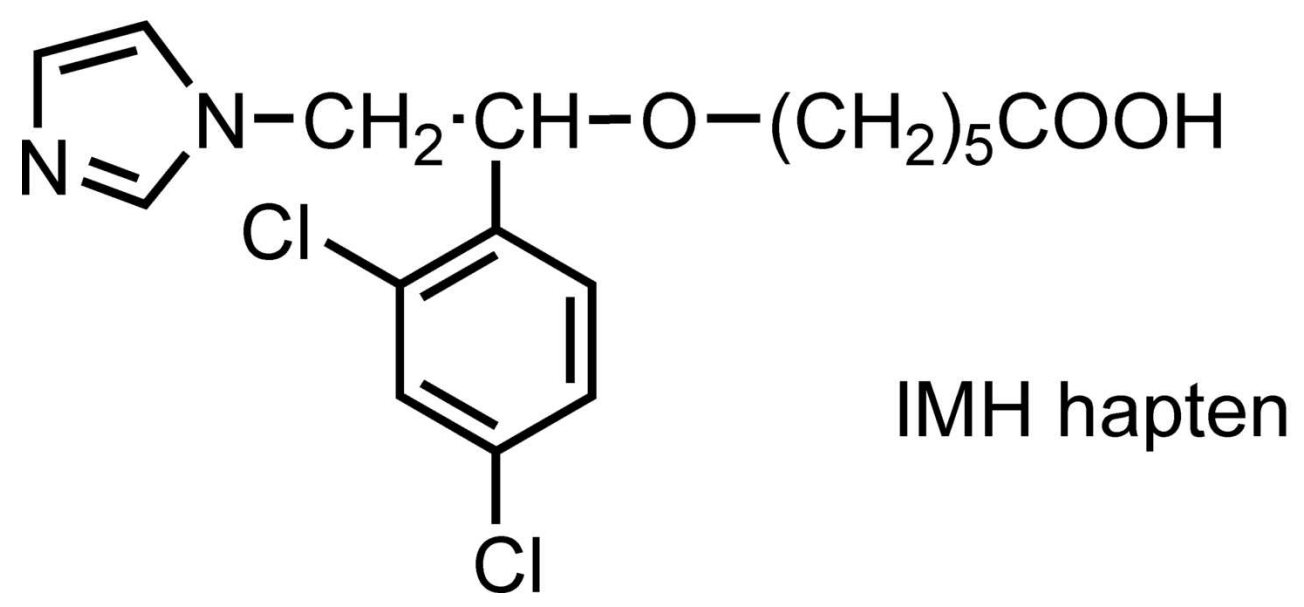

Figure 1. Structures of imazalil and of the IMH hapten. $63 \times 67 \mathrm{~mm}(600 \times 600 \mathrm{DPI})$ 


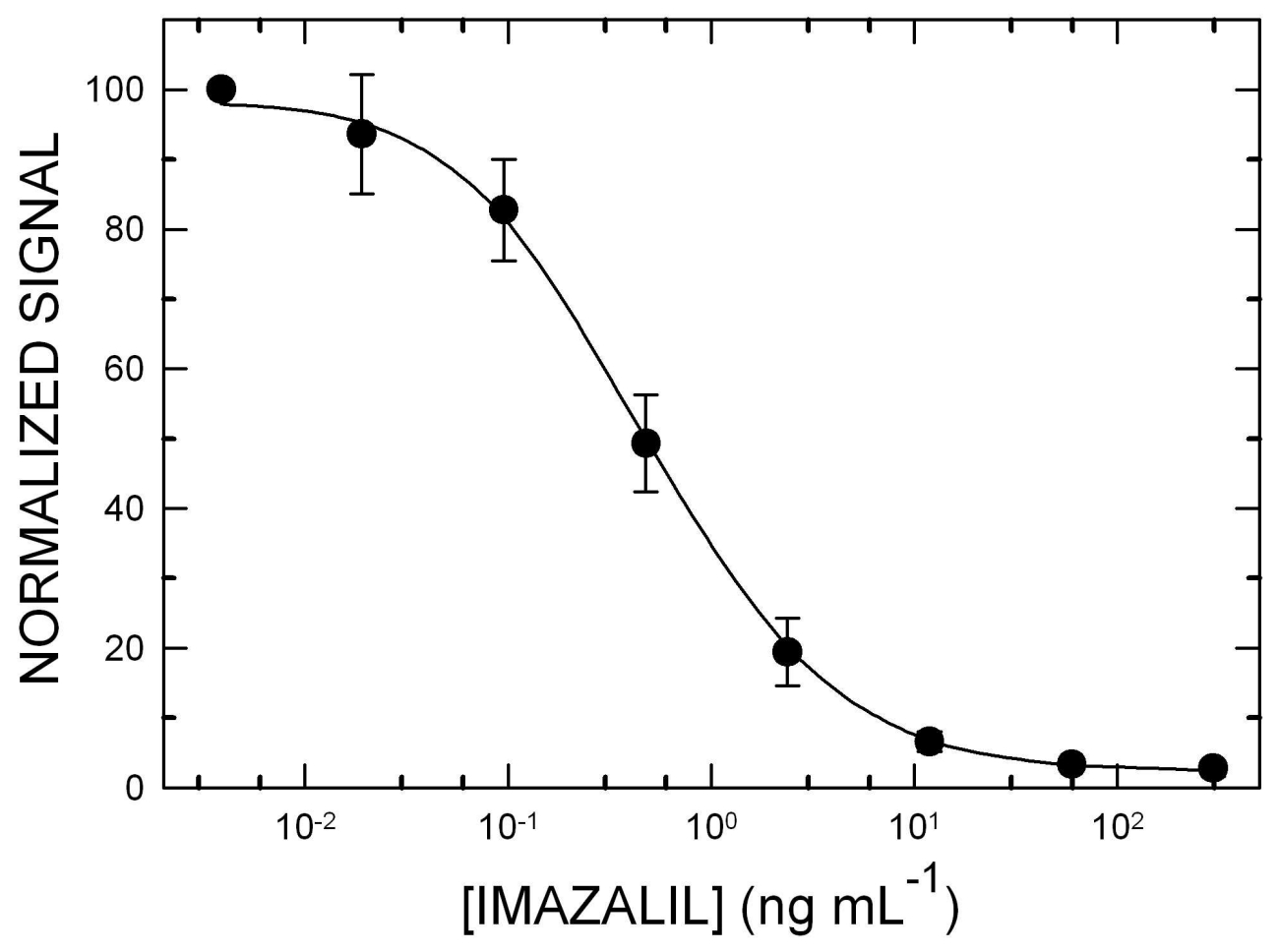

Figure 2. Normalized averaged standard curve for imazalil ELISA (100 X $\left.A_{490} / A_{\max }\right)$. Each point represents the mean of 8 values \pm standard deviation. $339 \times 299 \mathrm{~mm}(150 \times 150 \mathrm{DPI})$ 